\title{
Emission Trading Scheme and the Effect of Carbon Fee on Petroleum Refineries
}

\author{
Henry O. Orugba ${ }^{1 *}$, Samuel E. Ogbeide ${ }^{2}$ and Christian Osagie ${ }^{3}$ \\ ${ }^{1,2}$ Department of Chemical Engineering \\ University of Benin, Nigeria \\ ${ }^{3}$ Faculty of Environmental and Natural Sciences, Brandenburg University of Technology \\ Cottbus-Senftenberg, Germany \\ *Corresponding author's email: orugbahenry [AT] yahoo.com
}

\begin{abstract}
The high volume of green house gases released from petroleum refineries has contributed greatly to global warming. The crude distillation unit of a refinery being an energy-intensive unit generates high volume of greenhouse gases. Unlike solid and liquid pollutants that can easily be handled and treated, gaseous pollutants are difficult to handle once they are generated, hence an effective means of reducing their generation is paramount. Because of the cost penalty placed on defaulters, emission trading scheme has been an effective way of controlling the release of these obnoxious gases into the environment as refiners would seek alternative processing schemes that reduce emissions. The crude distillation unit of the refinery under study was simulated in Aspen Hysys. The unit was designed to process 125,000bpsd of a blend of three Nigerian crudes. Greenhouse gases from the unit were targeted from direct (heating sources) and indirect (electricity usage) respectively. The concept of global warming potential was adopted to estimate the carbon (iv) oxide equivalent of the greenhouse gases from the unit. A methodology to allocate emission quota to a refinery was developed and a carbon fee of $\$ 5$ per tonne was placed for above- limit emissions. The crude distillation unit was found to have a base generation of 491576.27tonne/yr of carbon (iv) oxide equivalent while it pays $\$ 491,576.25 p e r$ year for above-limit emission. The sensitivity analysis revealed that the gross profit is quite sensitive to carbon fee.
\end{abstract}

Keywords---- Green house gases; refinery; emission quota; carbon fee; global warming potential.

\section{INTRODUCTION}

The petroleum industry generates mainly gaseous pollutants and heavy metals in waste water stream (Chan et al., 2016). Carbon (iv) oxide, nitrogen oxides and methane, generally termed greenhouse gases (GHGs) generated from petroleum refineries are the prominent obnoxious gases that are responsible for global warming (Callan and Thoma, 2004; Amanda et al., 2010; Giwa et al., 2017). Greenhouse gases build-up in the atmosphere has increased so fast in the last two decades causing rapid rise of global temperature. There are different sources of gaseous emissions in the refineries, some of these sources include leakages from storage tanks and transport pipelines as well as combustion from furnaces and boilers. Of the various greenhouse gases, it has been established that $\mathrm{CO}_{2}$ is responsible for over $60 \%$ of the enhanced greenhouse gases effect. Carbon (iv) oxide is the most important greenhouse gas produced by combustion of fuel (Bhawana, 2013). $\mathrm{CO}_{2}$ emissions worldwide from oil refineries totaled about 700 million tonnes in 1994 and the baseline projection is that by 2020, refinery $\mathrm{CO}_{2}$ emissions will be about 840 million tonnes per year (EIA, 2000). The International Energy Agency (IEA, 2000) estimated that an average of about $10 \%$ of petroleum-related GHG emissions is from oil industry operations (exploration, production, refining and distribution). Combustion however is the major source of gaseous emissions from the refineries owning to the enormous volume of fossil fuel they burn to produce energy. Combustion processes in oil refineries and power plants produce flue gases which escape into the atmosphere constituting nuisance to human lives. Several approaches have been proposed by different bodies to cut down emissions of GHGs into the environment. Some of these approaches do have some drawbacks making it difficult for operators of refineries to adopt. For example, carbon capture and storage is very expensive and can cost even up to $\$ 162$ per ton of $\mathrm{CO}_{2}$ (Chan et al., 2016). Most refineries would prefer to vent their emissions directly in order to save cost. It is therefore important for the government of any country to adopt emission control strategies. The international community has addressed this global warming problem by introducing a market-based mechanism known as the Emission Trading Systems under the Kyoto Protocol which imposes binding limits to developed nations. Creating a price on GHGs emissions helps to correct an underlying market failure that led to increasing the concentrations of GHGs into the atmosphere. 


\section{BACKGROUND OF STUDY}

\subsection{Petroleum Refining GHG Emission sources}

GHGs are mainly produced from burning of fossil fuels and the petroleum refineries burn much of these fossil fuels in their operations. Therefore, the petroleum refining industry is a significant source of GHG emissions. Other processes units in the refinery like the FCC unit, hydrogen production unit and sulfur- recovery plants usually generate substantially high volume of $\mathrm{CO}_{2}$. The emission of $\mathrm{CH}_{4}$ is usually associated with process equipment leaks, crude oil storage tanks, delayed coking units and blow-down systems. GHGs emissions from petroleum refineries were estimated to be 214 million metric tons of $\mathrm{CO}_{2}$ equivalents $\left(\mathrm{CO}_{2} \mathrm{e}\right)$ based on production rates in 2005 (Coburn, 2007; US EPA, 2008).

Of all the green house gases generated from petroleum refineries, $\mathrm{CO}_{2}$ appears to be the most predominant, accounting for almost $98 \%$ of all GHG emissions at refineries. $\mathrm{CH}_{4}$ emissions are 4.7 million metric tons and accounts for $2.25 \%$ of petroleum refineries emissions. The relative magnitude of $\mathrm{CO}_{2}$ and $\mathrm{CH}_{4}$ emissions is dependent on the type of process unit and other characteristics of the refinery. Facilities that do not have catalytic cracking unit and hydrogen plants will tend to have fraction of their total GHG emission released as $\mathrm{CH}_{4}$. Stationary combustion sources are the largest sources of GHG emissions in refineries. They include process heaters, boilers, combustion turbines and similar devices. The largest process heaters are the atmospheric and vacuum furnaces and the catalytic reformer unit (if present at a refinery).

\subsection{GHGs emission regulations}

The International Energy Agency (IEA, 2000) in 1999 conducted a study on the estimation of global GHGs emissions in order to reduce emissions. Using a baseline scenario, emission was projected up to 2020 using compound growth rates and the World Energy Council projections for oil used as primary energy. A rise in emissions from $1083 \mathrm{mtCO}_{2} / \mathrm{yr}$ in 1990 to $1578 \mathrm{mtCO}_{2} / \mathrm{yr}$ in 2020 from refineries and petrochemicals together was obtained from the report. Many researchers have identified different strategies to reduce GHGs emissions from refineries. Some of the methods are as follows:

i. $\quad$ Energy efficiency which can be achieved through reducing energy use with consequent cost savings.

ii. Maximum $\mathrm{CO}_{2}$ reduction which can be achieved through $\mathrm{CO}_{2}$ capture/storage.

However, it must be noted that no refinery and any GHGs emitter is ready to employ any means to cut done emissions if it cuts into their profit, hence most of them have done well in energy efficiency not really with a view to reduce GHGs emissions but to save cost but very few have incorporated $\mathrm{CO}_{2}$ capture. The situation is very worrisome in Nigeria where none of the refineries is optimized, giving rise to unexpectedly high energy consumption and there are no strict air emission regulatory bodies.

The Kyoto protocol was an initiative of the United Nations Framework Convention on Climate Change that was approved in 2005 by 181 countries and the European Union with the objective of fighting global warming and climate change by reducing the emissions of GHGs to an average of 5\% against the 1990 levels over the five-year period 2008-2012. Facilities generating GHGs are faced with the challenge of either cutting down their emissions or pay in form of buying carbon credits or pay carbon tax (Yuvika, 2011). It is important for the Nigerian government to impose emission limits on refineries to force them to adopt severe methods to curb the enormous GHGs emissions from their facilities.

\subsection{The concept of carbon credits}

Carbon credits are digital certificates representing 1 tonne of carbon (iv) oxide. It is a permit issued to companies that generates carbon emissions into the environment over a period of time. A credit value is created by these certificates against one tonne of GHG emitted thereby regulating the volume of carbon emissions released into the environment. This permit is usually purchased from organizations whose activities like afforestation removes carbon (iv) oxide from the atmosphere. Carbon credits can also be purchased from companies investing in wind mills, biodiesel and co-generation (Bhawana, 2013).

Petroleum refineries are usually given emission quota and those that have exhausted their quota are to buy carbon credits for any above-limit tonne of GHGs they generate. On the other hand, those facilities that generates below their quota can sell their remaining credits. Carbon trading is the buying and selling of the right to emit a tonne of $\mathrm{CO}_{2}$ or its equivalent. Carbon emission trading is a mechanism designed to provide an economic incentive to limit GHGs emissions. Those emitters that can reduce at low cost do so and sell any spare permits to those that find it more expensive to cut emission hence creating profits for those that can reduce their emission and a reduced cost for those that cannot. The price stimulates innovation methods to reduce carbon emissions and markets to transparently price the cost of emission reduction.

\subsection{GHGs emissions in Nigeria}

Many developed and developing countries have come up with GHGs emission regulatory system to curb the problem of global warming (Yuvika, 2011). Despite the dangers of global warming and climate change posed by the release of GHGs into the atmosphere, the Nigerian government is yet to come up with strict regulations on the volume of GHGs emissions from high GHGs generating facilities like the refineries and power plants. This has resulted to uncontrolled release of GHGs from refineries around the countries. If this is not checked, the situation will be worsened in the future as more refineries and power plants are being built yearly to carter for the increased demand for transportation fuels and power generation. 


\section{METHODOLOGY}

The crude distillation unit of the refinery under study in this research was simulated with Aspen Hysys. The refinery was designed to produce more of light products. The capacity of the plant was 125,000BPSD using a blend of three Nigerian crudes- Agbami crude (API ${ }^{\circ}$ 48.4), Brass River crude (API ${ }^{\circ} 37.61$ ) and Ebok crude (API $\left.{ }^{\circ} 20.5\right)$. Data on assay of the crude oil was characterized using ASPEN HYSYS software. The blending process was carried out in such a way as to ensure that the plant's configuration is strictly adhered to. The process flow diagram of the crude distillation unit is shown in Figure 1.0

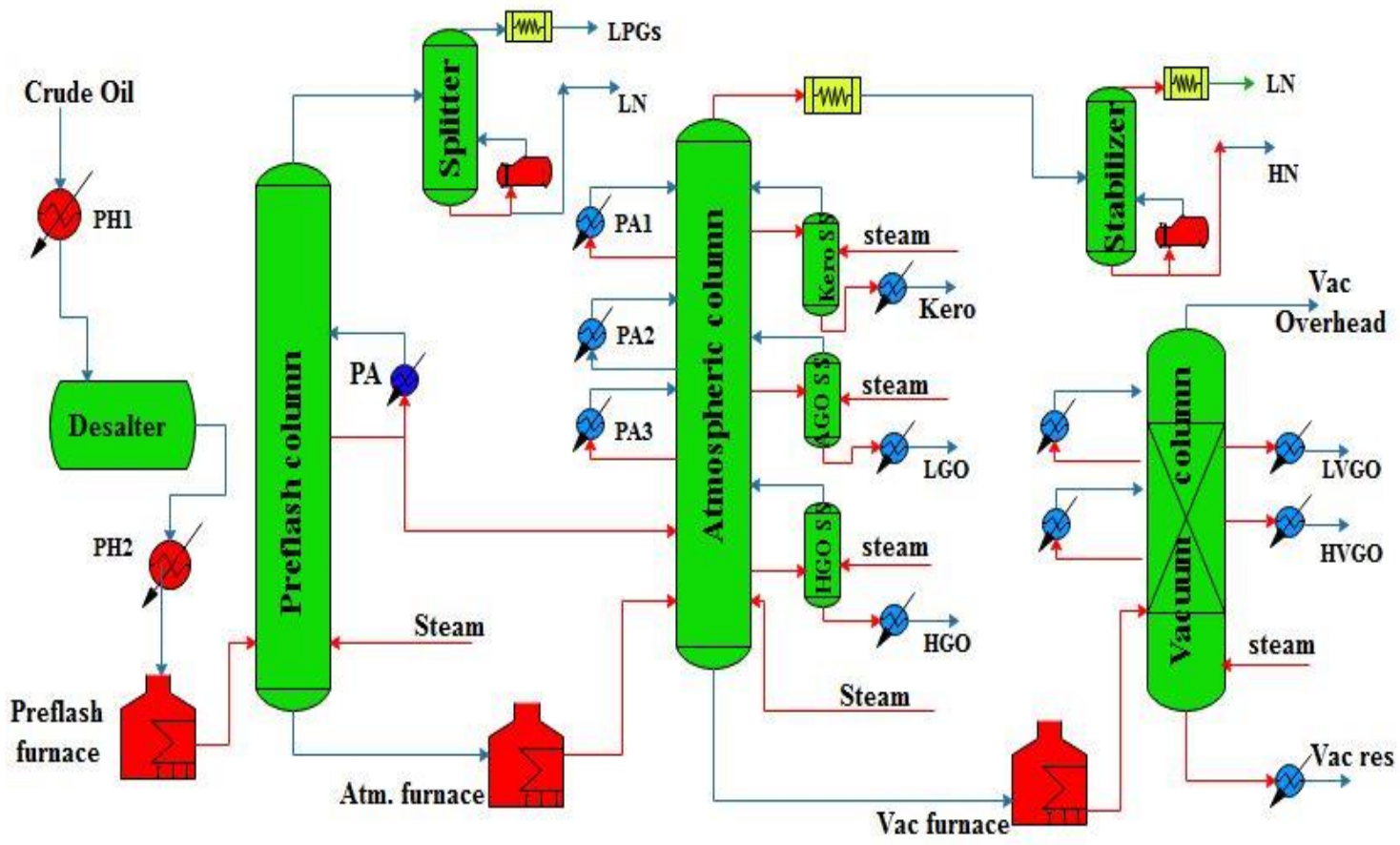

Figure 1.0 Process flow diagram of the crude distillation unit

Crude from storage entered the first preheating train to raise its temperature before it entered the desalter. Dissolved salts and associated impurities were removed at the desalter. The desalted crude entered the second preheating train which is a network of heat exchangers associated with the various downstream equipment. Much energy was recovered in this process which reduced the energy demand in the unit. The crude entered the preflash furnace to raise its temperature to $220^{\circ} \mathrm{C}$ before it was passed into the preflash column where light ends were stripped off the crude. The bottom crude leaving the preflash column was passed through the atmospheric furnace to further raise its temperature to $300^{\circ} \mathrm{C}$ before it entered the atmospheric column where kerosene, light gas oil and heavy gas oil were obtained as side draws while the overhead was naphtha that was sent to a stabilizer to separate it into light naphtha and heavy naphtha. The atmospheric column bottom was sent through the vacuum heater before it entered the vacuum column to produce the light vacuum gas oil and the heavy vacuum gas oil.

\subsection{Emission targeting}

The various sources from which the gaseous emissions were released were identified. Carbon (iv) oxide, methane and nitrous oxide were the three major air pollutants considered in this research. The extent of damage done to the environment is not the same for the three pollutants. The comparison of the ability of a GHG to trap heat in the atmosphere with respect to another gas is the concept of global warming potential (GWP). GWP is the temporal change in radiative forcing due to the instantaneous release of one kilogram of a gas expressed relative to the radiative forcing from the release of one kilogram of $\mathrm{CO}_{2}$. In order to accurately quantify the GHGs emissions emanating from the unit, emissions was evaluated on a carbon (iv) oxide equivalent $\left(\mathrm{CO}_{2} \mathrm{e}\right)$ basis. A unit (one pound) of methane harms the environment 25 times more than the same amount of $\mathrm{CO}_{2}$, so the GWP for $\mathrm{CH}_{4}$ is 25 . For $\mathrm{CO}_{2}, \mathrm{GWP}$ is 1 and for $\mathrm{N}_{2} \mathrm{O}$ it is 298 times the GWP for $\mathrm{CO}_{2}$. The emission of each pollutant is multiplied with its GWP and summed up to obtain the carbon (iv) oxide equivalent $\left(\mathrm{CO}_{2} \mathrm{e}\right)$. The emission targeting was carried out in two steps as follows:

\subsubsection{Emission targeting from direct sources}

Emissions from direct sources include emissions from heating utilities $\left(\mathrm{Q}_{\mathrm{H}}\right)$ which include the preflash heater $\left(\mathrm{Q}_{\mathrm{pfH}}\right)$, atmospheric heater $\left(\mathrm{Q}_{\mathrm{AtmH}}\right)$, vacuum heater $\left(\mathrm{Q}_{\mathrm{vacH}}\right)$, the splitter reboiler $\left(\mathrm{Q}_{\mathrm{splReb}}\right)$ and the stabilizer reboiler $\left(\mathrm{Q}_{\text {stabReb }}\right)$. The 
total amount of heat energy in million BTU (mmBtu) in all these units was calculated to obtain the activity data from heating utilities as follows:

$$
\begin{aligned}
& Q_{H}=Q_{P f H}+Q_{A t m H}+Q_{V a c H}+Q_{S p l \text { Reb }}+Q_{S t a b \text { Reb }} \\
= & 360.6 \mathrm{mmBtu} / \mathrm{h}
\end{aligned}
$$

The fuel used in heating in the refinery is fuel oil since it is readily available and cheap. For a mmBtu of fuel oil, the emission factors for the three major GHGs (pollutants) as well as their respective global warming potentials (GWP) were presented in Table 1

Table 1: Fuel Oil emission data and the GWP of the three major pollutants

\begin{tabular}{|c|c|c|}
\hline Pollutant & $\begin{array}{c}\mathrm{EF} / \mathrm{mmBtu} \\
(\mathrm{lbs} / \mathrm{mmBtu})\end{array}$ & GWP \\
\hline $\mathrm{CO}_{2}$ & 160.78 & 1 \\
\hline $\mathrm{CH}_{4}$ & 0.00661 & 25 \\
\hline $\mathrm{N}_{2} \mathrm{O}$ & 0.00132 & 298 \\
\hline
\end{tabular}

The carbon (iv) oxide equivalent $\left(\mathrm{CO}_{2} \mathrm{e}\right)$ from heating utilities in the unit was then calculated as follows:

$$
\begin{aligned}
& \left(C_{2} e\right)_{H}=\sum_{i=1}^{n}\left(E F_{i} \times G W P_{i}\right) \times Q_{H} \quad\left(\mathrm{i}=\mathrm{CO}_{2}, \mathrm{CH}_{4} \text { and } \mathrm{N}_{2} \mathrm{O}\right) \\
& =(160.78 \times 1+0.00661 \times 25+0.00132 \times 298) \times 360.6 \\
& =58,178.70 \mathrm{lb} / \mathrm{h}
\end{aligned}
$$

\subsubsection{Emission targeting from indirect sources}

Emissions from indirect sources in the crude distillation unit include the electricity supplied to power the various condensers- the preflash condenser $\left(\mathrm{Q}_{\mathrm{pfCON}}\right)$, the atmospheric condenser $\left(\mathrm{Q}_{\mathrm{AtmCON}}\right)$, the splitter condenser $\left(\mathrm{Q}_{\mathrm{SpCON}}\right)$ and the stabilizer condenser $\left(\mathrm{Q}_{\mathrm{StabCON}}\right)$ as well as electricity used in the various pump arounds summed up as total pump around duty $\left(\mathrm{Q}_{\mathrm{TPA}}\right)$. The total amount of electrical energy in megawatt hour $(\mathrm{mWh})$ in all these units was calculated to obtain the activity data from electricity consumption in the crude distillation unit as follows:

$$
\begin{aligned}
& Q_{E}=Q_{\text {PfCON }}+Q_{\text {AtmCON }}+Q_{\text {SpCON }}+Q_{\text {StabCON }}+Q_{\text {TPA }} \\
& =118.4 \mathrm{mWhr}
\end{aligned}
$$

For a megawatt hour of electricity supplied, the emission factors for the three major GHGs (pollutants) as well as their respective global warming potentials (GWP) were presented in Table 2.

Table 2: Electricity emission data and the GWP of the three major pollutants

\begin{tabular}{|c|c|c|}
\hline Pollutant & $\begin{array}{c}\mathrm{EF} / \mathrm{mWh} \\
(\mathrm{lbs} / \mathrm{mWh})\end{array}$ & GWP \\
\hline $\mathrm{CO}_{2}$ & 650.31 & 1 \\
\hline $\mathrm{CH}_{4}$ & 0.03112 & 25 \\
\hline $\mathrm{N}_{2} \mathrm{O}$ & 0.00567 & 298 \\
\hline
\end{tabular}

The carbon (iv) oxide equivalent $\left(\mathrm{CO}_{2} \mathrm{e}\right)$ from electricity demand in the unit was then calculated as follows:

$$
\begin{aligned}
& \left(\mathrm{CO}_{2} e\right)_{E}=\sum_{i=1}^{n}\left(E F_{i} \mathrm{x} G W P_{i}\right) \times Q_{E} \quad\left(\mathrm{i}=\mathrm{CO}_{2}, \mathrm{CH}_{4} \text { and } \mathrm{N}_{2}\right) \\
& =(650.31 \times 1+0.03112 \times 25+0.00567 \times 298) \times 118.4 \\
& =77,288.8 \mathrm{lb} / \mathrm{h}
\end{aligned}
$$




\subsubsection{Total GHGs emission from the unit}

The total GHGs emitted from the crude distillation was calculated as the total carbon (iv) oxide equivalent as pounds (lbs) of carbon (iv) oxide equivalent by summing the $\mathrm{CO}_{2} \mathrm{e}$ from both heating utilities and electricity as follows:

$$
\begin{gathered}
(\text { GHGs })_{\text {Total }}=\left(\mathrm{CO}_{2} e\right)_{H}+\left(\mathrm{CO}_{2} e\right)_{E} \\
=58,178.70+77,288.8 \\
=135,467.52 \mathrm{lb} / \mathrm{h}
\end{gathered}
$$

If the plant was operated for $8000 \mathrm{hrs}$ annually, the total GHGs emission was obtained as:

$$
\begin{array}{r}
\left(\mathrm{CO}_{2} e\right)_{\text {Total }}=135,467.52 \times 8000 \\
=108.37 \times 10^{7} \mathrm{lb} / \mathrm{yr} \\
=491576.27 \mathrm{tonne} / \mathrm{yr}
\end{array}
$$

\subsubsection{Assumptions made in allocating emission quota to a facility}

The assumptions made in allocating emissions quota to the facility were presented in Table 3.

Table 3: Assumptions for the allocation of emission quota to a refinery

\begin{tabular}{|l|c|}
\hline \multicolumn{1}{|c|}{ Parameter } & Value \\
\hline Free allowances & $80 \%$ of emissions \\
\hline Carbon fee (\$/tonne) & 5 \\
\hline
\end{tabular}

$$
\text { emission allowed } \quad \begin{aligned}
C_{L} & =80 \% \text { of base emission } \\
& =0.8 \times 491576.27 \\
& =393261.02 \text { tonne } / y r
\end{aligned}
$$

\subsection{Effect of carbon fee on the gross profit}

The gross profit model of the crude distillation unit was developed as follows:

Where

$$
\emptyset=\psi_{1}-\psi_{2}-\psi_{3}
$$

$\emptyset$ represents gross profit

$\psi_{1}$ represents the revenue from products sale

$\psi_{2}$ represents operational costs

$\psi_{3}$ represents emission penalties/credits

The total revenue from products sale was calculated as follows:

$$
\psi_{1}=\sum_{i=1}^{10} X_{i} P_{i} \quad(i=1,2, \ldots, 10)
$$

Where $i$ represents the various products from the unit. The cost per barrel as well as the unit price of the various products obtained from the crude distillation unit are presented in Tables 4 and 5 as follows:

Table 4: 2018 Crude oil prices (\$/bbl) :US Energy Information Administration

\begin{tabular}{|l|c|}
\hline \multicolumn{1}{|c|}{ Month } & Price $(\$ / \mathrm{bbl})$ \\
\hline January & 55.73 \\
\hline February & 53.42 \\
\hline March & 53.35 \\
\hline April & 58.53 \\
\hline May & 62.45 \\
\hline June Average & 62.45 \\
\hline \multicolumn{2}{|c|}{ Ave } \\
\hline
\end{tabular}


Table 5: US Refiner prices of petroleum products in 2018 (\$/bbl)

\begin{tabular}{|l|c|c|c|c|c|c|}
\hline \multirow{2}{*}{ Month } & \multirow{2}{*}{$\begin{array}{l}\text { LPG } \\
\text { \$/m }\end{array}$} & \multicolumn{5}{|c|}{$\$ / \mathrm{bbl}$} \\
\cline { 3 - 7 } & $\mathbf{m} \mathrm{m}^{3}$ & Naphtha & Kerosene & Diesel & Fuel oil & Residual oil \\
\hline January & 256.511 & 88.536 & $\mathrm{~W}$ & 90.048 & 92.652 & 63.294 \\
\hline February & 250.435 & 89.334 & $\mathrm{~W}$ & 88.494 & 99.33 & 62.58 \\
\hline March & 222.433 & 90.72 & $\mathrm{~W}$ & 87.192 & 104.328 & 60.984 \\
\hline April & 221.640 & 97.23 & $\mathrm{~W}$ & 92.442 & 104.412 & 63.168 \\
\hline May & 241.982 & 104.748 & 135.198 & 99.456 & 104.076 & 70.014 \\
\hline June & 233.264 & 103.698 & 138.264 & 98.28 & 101.346 & 72.702 \\
\hline Average & 237.712 & 95.711 & 136.731 & 92.652 & 101.024 & 65.457 \\
\hline
\end{tabular}

The Operational Cost was obtained as follows:

$$
\psi_{2}=(\text { Cost of raw materials })+(\text { Energy cost })+(\text { Utilities cost })
$$

The cost of raw material was calculated by multiplying the feed flowrate by the cost per unit of feed as follows

$$
C_{r m}=F_{f} \times C_{f}
$$

The energy cost was obtained as follows:

$$
C_{\text {en }}=\left(\sum_{i=1}^{n} \Delta H_{\text {furn }, i} \times C_{f u r n, i}\right)+\left(\sum_{i=1}^{n} \Delta H_{R e b, i} \times C_{R e b, i}\right)
$$

The utility costs was obtained as follows

$C_{u t}=\left(\sum_{i=1}^{n} F S_{s t, i}\right) \times C_{S}+\left(\sum_{i=1}^{n} \Delta H_{c o n d, i}\right) \times C_{c o n d}+\left(\sum_{i=1}^{n} \Delta H_{P A, i}\right) \times C_{p a}+\left(\sum_{i=1}^{n} F W_{W a t, i}\right) \times C_{w a t}$

The unit cost of the utilities used in the crude distillation unit are presented in Table 6.

Table 6: Utilities and their unit costs

\begin{tabular}{|l|c|}
\hline \multicolumn{1}{|c|}{ Products } & Unit price $(\$)$ \\
\hline Electricity & $0.106 / \mathrm{kWh}$ \\
\hline Steam & $0.00862 / \mathrm{lb}$ \\
\hline Furnace operating cost & $0.0000117 / \mathrm{Btu}$ \\
\hline Waste water treatment & $0.227 / \mathrm{bl}$ \\
\hline
\end{tabular}

The Emissions Cost was calculated as

$C_{e m}=\left[\left(C_{L}-C_{2} e\right) \times C_{C f}+F_{w} \times C_{t}\right.$

Combining all the sub equations from equations 8-13, a general function of the Gross Profit was obtained

$$
\begin{aligned}
& G p=\sum_{i=1}^{n} X_{i} P_{i}-\left[\left(F_{f} \times C_{f}\right)+\left(\sum_{i=1}^{n} \Delta H \quad \mathrm{x} C_{f u r n, i}\right)+\left(\sum_{i=1}^{n} \Delta H_{R e b, i} \times C_{R e b, i}\right)\right. \\
& +\left(\sum_{i=1}^{n} F S_{s t, i}^{n}\right) \times C_{o p t}+\left(\sum_{i=1}^{n} F \underset{w a t, i}{ }\right) \times C_{w a t}+\left(\sum_{i=1}^{n} \Delta H_{c o n d, i}\right) \times C_{o p t} \\
& +\left(\sum_{i=1}^{n} \Delta H{ }_{P A, i}\right) \times C_{o p t}+\left(\left(C_{L}-C O_{2} e\right) \times C_{C f}\right)+F_{w} \times C_{t}
\end{aligned}
$$

\subsection{Sensitivity Analysis of carbon fee on gross profit}

The effect of carbon fee on the gross profit of the crude distillation unit was investigated and the result is presented in Figure 2.0. 


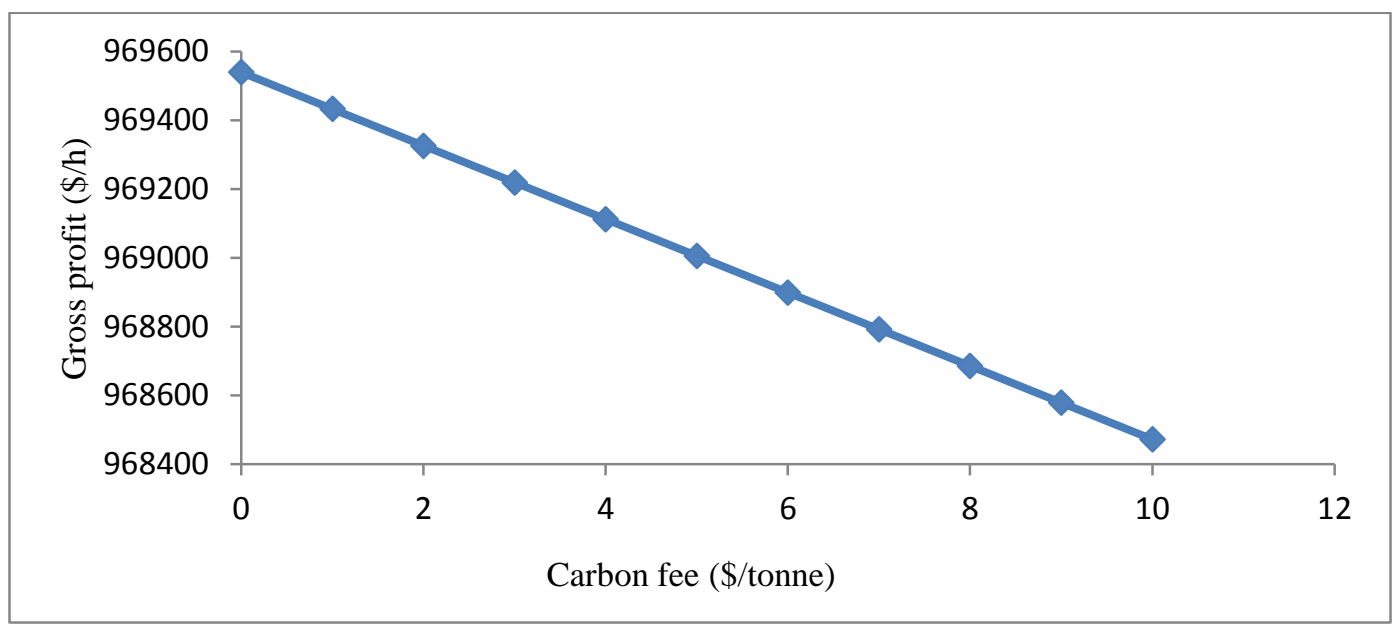

Figure 2: Sensitivity analysis of gross profit with carbon fee

The sensitivity analysis of the refinery gross profit and carbon fee is presented in Figure 2. It can be observed from the plot that the gross profit from the unit is quite sensitive to carbon fee and the worst scenario was observed when the carbon fee was $\$ 10$ per tonne of carbon (iv) oxide equivalent. It can therefore be concluded that the higher the carbon fee charged, the lower the gross profit from the distillation unit hence refiners will be forced to use the processing schemes that reduce the emission of greenhouse gases into the environment so as to reduce emission cost.

\section{CONCLUSIONS}

A useful study to target and quantify greenhouse gases emanating from the crude distillation unit of a petroleum refinery has been carried out. The emission trading scheme adopted in the study has revealed the effect of carbon charges on the gross profit from the unit. The carbon charges is quite sensitive to the gross profit as the gross profit falls sharply with increased carbon charges. This will challenge operators of petroleum refineries to adopt processing schemes that reduce the generation of these obnoxious gases into the environment and the impact is safer environment with less threat of global warming dangers

$\mathrm{C}_{\mathrm{em}}$ : Emission cost

\section{NOMENCLATURE}

$\mathrm{C}_{\mathrm{en}}$ : Cost of energy

$\mathrm{C}_{\mathrm{f}}$ : Cost of feed per unit (crude)

$\mathrm{C}_{\text {furn }}$ : Cost of providing unit heat in a furnace

$\mathrm{C}_{\mathrm{L}}$ : Allowable carbon limit

$\mathrm{C}_{\text {opt}}$ : Operating cost

$\mathrm{C}_{\mathrm{PA}}$ : Cost of removing unit heat in a pump around

$\mathrm{C}_{\mathrm{Reb}}$ : Cost of providing unit heat in a reboiler

$\mathrm{C}_{\mathrm{rm}}$ : Cost of raw material

$\mathrm{C}_{\mathrm{s}}$ : Cost of unit mass of steam

$\mathrm{C}_{\mathrm{t}}$ : Cost of treating unit volume of waste water

$\mathrm{C}_{\mathrm{ut}}$ : Cost of utilities

$\mathrm{C}_{\text {wat }}$ : Cost of unit mass of water

$\mathrm{EF}_{\mathrm{i}}$ : Emission factor from gas $\mathrm{i}$

FS: Flowrate of steam 
FW: Flowrate of water

GP: Gross profit

GWP $\mathrm{i}_{\mathrm{i}}$ Global warming potential of pollutant $\mathrm{i}$

$\emptyset$ : Profit

PAD $_{\mathrm{i}}$ : Duty of pump around $\mathrm{i}$

$\mathrm{PAF}_{\mathrm{i}}$ : Flowrate of pump around $\mathrm{i}$

$\mathrm{P}_{\mathrm{i}}$ : Unit price of product $\mathrm{i}$

Q AtmCOND: Heat duty in the atmospheric condenser

Q AtmH: Heat demand in atmospheric column heater

$\mathrm{Q}_{\mathrm{E}}$ : Activity data from electricity utility

$\mathrm{Q}_{\mathrm{H}}$ : Activity data from hot utilities

$\mathrm{QPA}_{\mathrm{PA}}$ : Heat duty in the total pump arounds

$\mathrm{Q}_{\mathrm{pfCOND}}$ : Heat duty in the preflash condenser

$\mathrm{Q}_{\mathrm{pfH}}$ : Heat demand in preflash heater

$\mathrm{Q}_{\text {Reb}}$ : Heat demand in reboiler

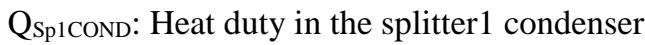

Q ${ }_{\text {Sp2COND }}$ : Heat duty in the splitter2 condenser

$\mathrm{Q}_{\text {steam: }}$ Heat demand in steam production

$Q_{\text {vach: Heat demand in vacuum column heater }}$

$\mathrm{FSS}_{\mathrm{i}}$ : Flowrate of stripping steam i

$\mathrm{x}_{\mathrm{i}}$ : Unit volume of product $\mathrm{i}$

$\left(\mathrm{CO}_{2} \mathrm{e}\right)_{\mathrm{E}}$ : Carbon (iv) oxide equivalent from electrical utilities

$\left(\mathrm{CO}_{2} \mathrm{e}\right)_{\mathrm{H}}$ : Carbon (iv) oxide equivalent from hot utilities

$(\mathrm{GHGs})_{\text {Total }}$ Total green house gas

$\Delta_{\text {HCOND: }}$ Heat duty in condensers

$\Delta_{\text {Hfurn: Heat duty in furnaces }}$

$\Delta_{\mathrm{HPA}}$ : Heat duty in pump arounds

$\Delta_{\text {HReb: }}$ Heat duty in a reboiler

$\psi_{1}$ : Revenue from product sale

$\psi_{2}$ : Operational cost

$\psi_{3}$ : Emission penalty/credits 


\section{REFERENCES}

- Aizebeokhal, A.P., 2009. Global Warming and Climate Change: Realities, Uncertainties and Measures. International Journal of Physical Sciences, 4(13), 868-879.

- Amanda, H.L., Noor, Z.M., Raman, A.A., 2010. Carbon Accounting Initiatives: A case study of a Petroleum Refinery in Malaysia to prepare for future Carbon- Market. Journal of Engineering Science and Technology, $5(2), 223-231$

- Callan, S.J., and Thoma, J.M., 2004. Environmental Economics and Management: Theory, Policy and Applications. ( $3^{\text {rd }}$ Ed.). Thomas South-Western, 78-117.

- Chan, W.N., Walter, A., Sugiyama, M.I. and Borges, G.C., 2016. Assessment of $\mathrm{CO}_{2}$ Emission Mitigation for a Brazilian Oil Refinery. Brazilian Journal of Chemical Engineering. 33(4), 835-850.

- Coburn, J. 2007. Greenhouse Gas Industry Profile for the Petroleum Refining Industry prepared for U.S Environmental Protection Agency, Washington, DC. Contract No. GS-10F-0283K, June 11.

- EIA (Energy Information Administration).2000. Refinery Capacity Report 2000. Prepared by the Energy Information Administration, Washington, DC. June 23.

- Giwa, S.O., Sulaiman, M.A., Nwaokocha, C.N., 2017. Inventory of GHGs Emissions from Gasoline and Diesel Consumption in Nigeria. Nigerian Journal of Technological Development. 14(1), 1-12.

- Iduh, J.J., Phil, M. and Kelvin, E.E., 2016. The Potential Reduction of Carbon dioxide $\left(\mathrm{CO}_{2}\right)$ Emissions from Gas Flaring in Nigeria's Oil and Gas Industry through Alternative Productive Use. Environment. 3(31).

- Yuvika, G.2011. Carbon Credit: A step towards Green Environment. Global Journal of Management and Business Research, 11(6).

- Bhawana, B. 2013. Future of Carbon Trading: A Business that works for Global Environment. International Journal of Science Environment, 2(1), 115-121. 